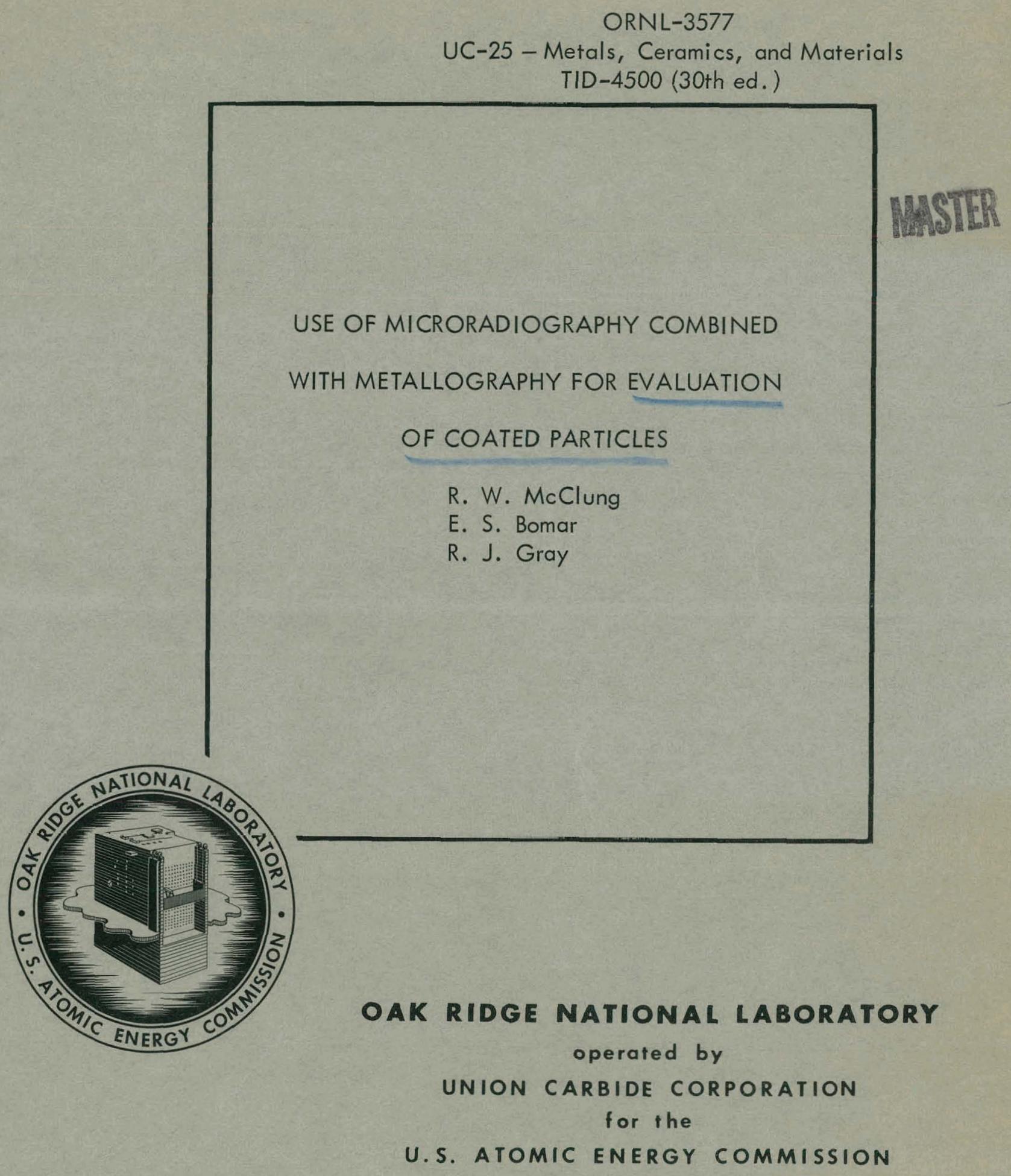




\section{DISCLAIMER}

This report was prepared as an account of work sponsored by an agency of the United States Government. Neither the United States Government nor any agency Thereof, nor any of their employees, makes any warranty, express or implied, or assumes any legal liability or responsibility for the accuracy, completeness, or usefulness of any information, apparatus, product, or process disclosed, or represents that its use would not infringe privately owned rights. Reference herein to any specific commercial product, process, or service by trade name, trademark, manufacturer, or otherwise does not necessarily constitute or imply its endorsement, recommendation, or favoring by the United States Government or any agency thereof. The views and opinions of authors expressed herein do not necessarily state or reflect those of the United States Government or any agency thereof. 


\section{DISCLAIMER}

Portions of this document may be illegible in electronic image products. Images are produced from the best available original document. 
This report was prepared as an account of Government sponsored work. Neither the United States, nor the Commission, nor any person acting on behalf of the Commission:

A. Makes any warranty or representation, expressed or implied, with respect to the accuracy, completeness, or usefulness of the information contained in this report, or that the use of any information, apparatus, method, or process disclosed in this report may not infringe privately owned rights; or

B. Assumes any liabilities with respect to the use of, or for damages resulting from the use of any information, apparatus, method, or process disclosed in this report.

As used in the above, "person acting on behalf of the Commission" includes any employee or contractor of the Commission, or employee of such contractor, to the extent that such employee or contractor of the Commission, or employee of such contractor prepares, disseminates, or provides access to, any information pursuant to his employment or contract with the Commission, or his employment with such contractor. 
ORNL-3577

Contract No. W-7405-eng-26

METALS AND CERAMICS DIVISION

USE OF MICRORADIOGRAPHY COMBINED WITH METALLOGRAPHY FOR EVALUATION OF COATED PARTICLES

R. W. McClung, E. S. Bomar, and R. J. Gray

JUNE 1964

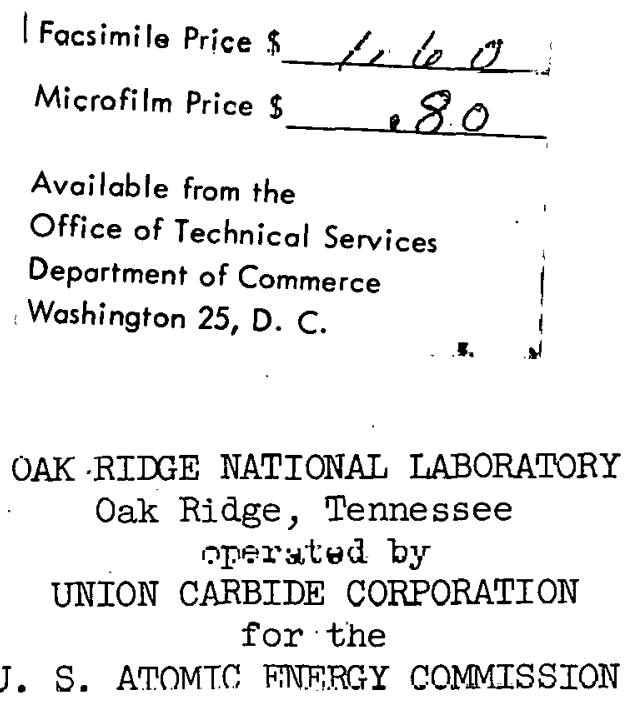




\title{
USE OF MICRORADIOGRAPHY COMBINED WITH METALLOGRAPHY FOR EVALUATION OF COATED PARTICLES
}

R. W. McClung, E. S. Bomar, and R. J. Gray

\begin{abstract}
The proposed use of nuclear fuels coated with pyrolytic carbon has made it neccisary to devise techniques for evaluating them. Metallographic techniques, modified to accommodate the spherical particle configuration, have proved quite useful for observing the structure of both the cladding and the core. For nondestructive examination, special low-voltage radiographic techniques have been developed. By employing extremely fine grained photographic emulsions, optical magnification can be used to make very accurate measurements of the core diameter and coating thickness, and, in addition, the core and coating integrity can be evaluated. The combination of the methods permits the use of the best feature of each toward the evaluation of coated particles.
\end{abstract}

\section{INTRODUCTION}

Two standard metallurgical tools - metallography and radiography have been modified to solve an unusual evaluation problem related to an all-ceramic nuclear fuel element. However, these techiques are not limited to nuclear technology.

The all-ceramic fuel-element concept ${ }^{1-3}$ for which the se techniques were developed was that of small spheroids of uranium and thorium carbide dispersed through a graphite matrix. The spheroids, which are about 0.010 in. in diameter, had to be coated with pyrolytic carbon to prevent the fission products produced during reactor operation from escaping into the coolant. In order to determine the acceptability of a given batch of coated fuel particles, they had to be examined for structural characteristics, carbon-coating thickness, fuel-particle shape, and the presence

1 "Improvcd Fuel Elementis," Metal Progr. 79(4), 93 (1961) (excerpts from address by F. K. Pittman).

2 "Coated-Particle Fuels - Promise and Problems," Nucleorics 19(3), 96-98 (1961) (data supplied ky R. W. Dayton of BMI).

${ }^{3} \mathrm{~J}$. H. Oxley et al., "Microminiaturized Fuel Elements," Ind. Eng. Chem., Prod. Res. Develop. I (2), 102-07 (1962). 
of uranium diffusion in the carbon coating. These quality-control requirements were met by use of a modified metallographic technique and a novel adaptation of the radiographic technique through the use of special photographic film and low-voltage $x$-ray energy.

\section{Modified Metallographic Procedure}

The use of metallography for microstructural evaluation was developed during the study of uranium carbide as a fucl material; the preparation and examination of samples for determination of composition, density, and homogeneity are somewhat, routine.4,5 With the Iritroduction of the carbon coating and because of the small size of the fuel particle in the present samples, this technique had to be modified. Basically, the modification 6,7 consists of using an epoxy resin ${ }^{8}$ which provides good adherence for the spherical particles and mounting the particles so that they are at different levels in the special mountings. This modification permits a median plane to be examined microscopically to show the columnar coating displayed in Fig. 1 or the laminar coating displayed in Fig. 2 and the minute details of the cores.

The metallographic examination, while necessary and informative, is limited in the accuracy of core measurements in relation to overall particle size, coating thickness, and detection of core fragments or fuel diffusion in the coating. It also has the disadvantage of requiring destruction of the particle during preparation of the sample for examination. Therefore, it was decided to investigate the use of radiography, extended to microscopic application, in combination with metallography to overcome the deficiencies of the latter.

${ }^{4}$ M. W. Mallet, A. F. Gerds, and D. A. Vaughn, Uranium Sesquicarbide, AECD-3060 (Jan. 30, 1950).

5R. J. Uray, W. C. Thurber, and C. K. H. DuBose, Preparation and Metallography of Arc-Melted Uranium Carbides, ORNL-2446 (Dec. 27, 1957).

${ }^{6}$ C. K. H. DuBose and R. J. Gray, Metallography of Pyrolytic Carbon Coated and Uncoated Uranium Carbide Spheres, ORNL TM-91 (March 21, 1962).

${ }^{7}$ C. K. H. DuBose and R. J. Gray, Metallographic Examination of Pyrolytic Carbon and Uncoated Uranium Carbide Particles, ORNL TM-52I (June 25, 1963).

${ }^{8}$ Araldite, Ciba Products Corporation, Fairlawn, New Jersey. 


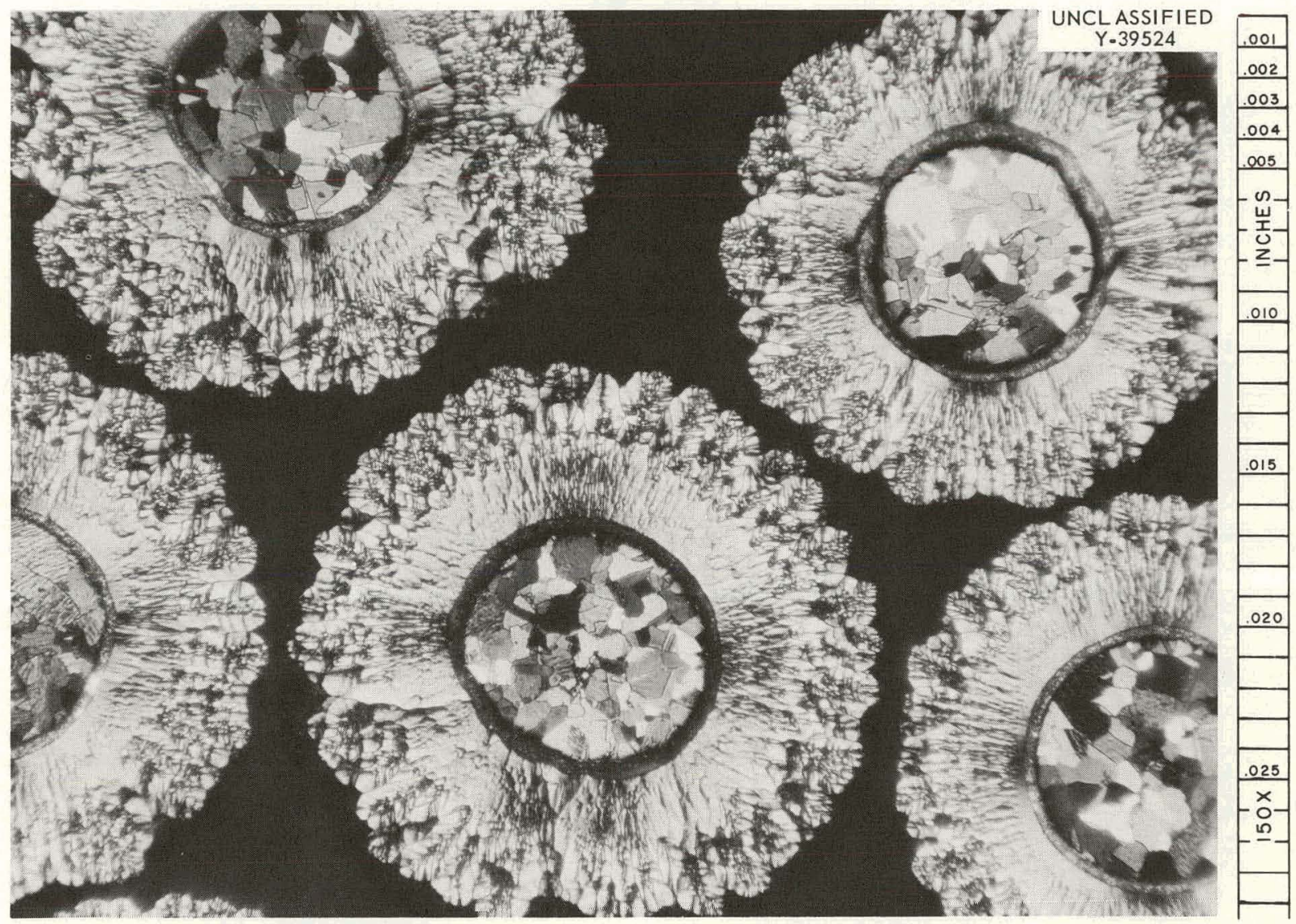

Fig. 1. Mctallographically Prepared Median Plane View of Columnar Coating on Uranium Carbide. Polarized-light. Uranium carbide etchant: equal parts $\mathrm{HNO}_{3}, \mathrm{CH}_{3} \mathrm{COOH}, \mathrm{H}_{2} \mathrm{O}$. 


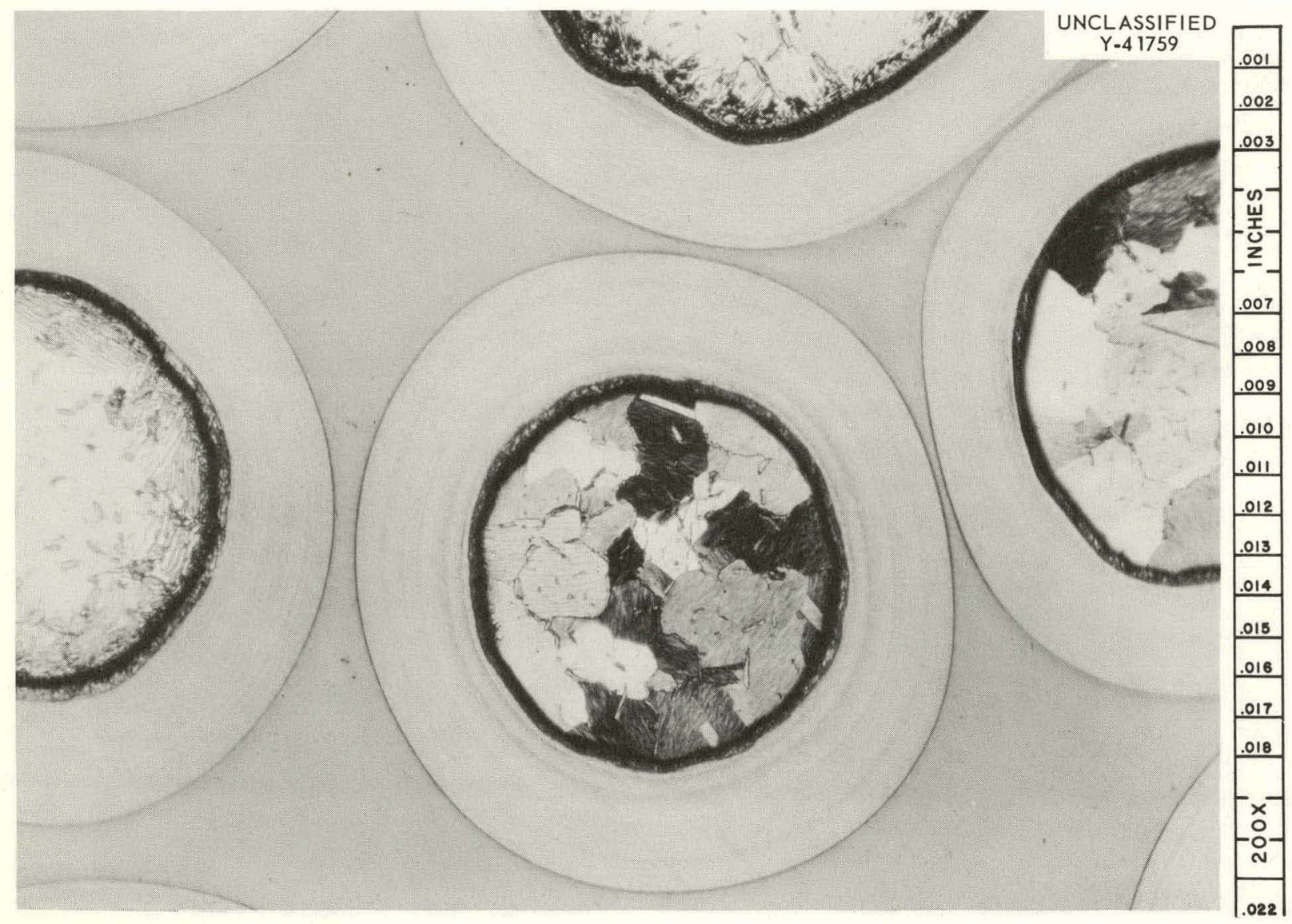

Fig. 2. Metallographically Prepared Median Plane View of Laminar Coating on Uranium Carbide. Bright-field. Uranium carbide etchant: equal parts $\mathrm{HNO}_{3}, \mathrm{CH}_{3} \mathrm{COOH}, \mathrm{H}_{2} \mathrm{O}$. 


\section{Radiographic Procedure}

The application of radiography to the evaluation of very small coated particles required extensive modification to conventional techniques. As is well known, the radiographic method consists of transmitting a beam of $\mathrm{x}$ or gamma radiation through a test specimen and recording the transmitted radiation intensity on a medium such as film. Variations in the transmission properties of the specimen will cause associated variations on the recording medium. For radiography to be useful, the radiation absorption of the specimen must vary enough for an interpretable contrast of density to be achieved on the film or other detector. The transmission properties are a function of the absorption coefficient (which is energy dependent) and the specimen thickness. The very small dimensions of the coated particles and the low-absorption coefficient of the pyrolytic carbon coating made it necessary to use low-energy (low-kilovoltage) irradiation.

Equipment

The equipment used in the program consisted of commercial radiographic instrumentation modified to provide better control over $x$-ray energy and exposure time. The low-kilovoltage techniques previously developed for the evaluation of beryllium tubing ${ }^{9}$ and other thin sections ${ }^{10}$ of beryllium, aluminum, and steel had to be modified in order for the ultimate in sensitivity to be achieved. The necessary steps included removing all extraneous material that could cause absorption, scattering, or uneven filtration of the soft $x$-ray beam between the $x$-ray target and the detector film. The removal of the radiation-absorbing material was effected by use of an $x$-ray tube head containing a beryllium window only $0.008 \mathrm{in}$. thick and a helium-atmosphere chamber between the $\mathrm{x}$-ray head and the specimen, since even air is an effective attenuator for the $\mathrm{x}$ rays at the energy level required. The helium was retained in the chamber by

${ }^{9}$ R. W. McClung, "Development of Nondestructive Testing Techniques for Thin-Wall Beryllium Tubing," pp 480-96 in International Conference on the Metallurgy of Beryllium, London, 1961, Proceedings, Chapman \& Hall, London, 1963 (Institute of Metals Monograph and Report Series No. 28).

10 R. W. McClung, "Techniques for Low-Voltage Radiography," Nondestructive Testing $\stackrel{20}{=}(4), 248-53$ (1962). 
thin (0.0005 in.) polyethylene diaphragms, which had no measurable effect on the $x$-ray transmission. Figure 3 shows the helium chamber and arrangement for coated-particle microradiography. An additional means of reducing unnecessary absorption was the substitution of bare film or plates for the cassette or film holder, which would have attenuated and changed the character of the radiation. This change necessitated the use of darkroom exposure techniques.

X-Ray Emulsions and Developing

Several different detectors were used in the program. The resulting radiographs when viewed at high magnifications revealed the core and coatings of the carbide particles. Type $M$ radiographic film was successfully viewed at about 60x, at which magnification the grain size of the emulsion became very evident. Nuclear track plates were used with about the same success as type M film. Very fine grained emulsions on Eastman high-resolution glass plates having a reported resolution capability of 1500 lines/mm were viewed at up to 500x with little difficulty caused by emulsion grain size; the particle and coating images were very sharp. It is felt that the limit on detail or resolution in the plates was due to electron diffusion in the emulsion, which is rated ${ }^{11}$ at about $1 \mu$ at the energy level being used.

of the several high-contrast, fine-grain developing solutions tested for the high-resolution plates, the standard $\mathrm{x}$-ray film developer was found to be as good as or better than any other solution tested and had the added advantage of being near the $x$-ray exposure room. Considerable care was exercised in handling and drying the high-resolution plates to prevent undesirable artifacts caused by contamination.

Exposure Requirements

The energy levels used for particle evaluation varied up to about $10 \mathrm{kvp}$, at which energy the exposure is only a few minutes for the $\mathrm{x}$-ray film. Because of the very thin emulsion and fine grain size of the highresolution plates, they responded very slowly to the $\mathrm{x}$ rays and required

${ }^{11}$ D. E. Iea, Actions of Radiations on Living Cells, p 24, Cambridge University Press, New York, 1947. 
UNCLASSIFIED

ORNL-LR-DWG 70755

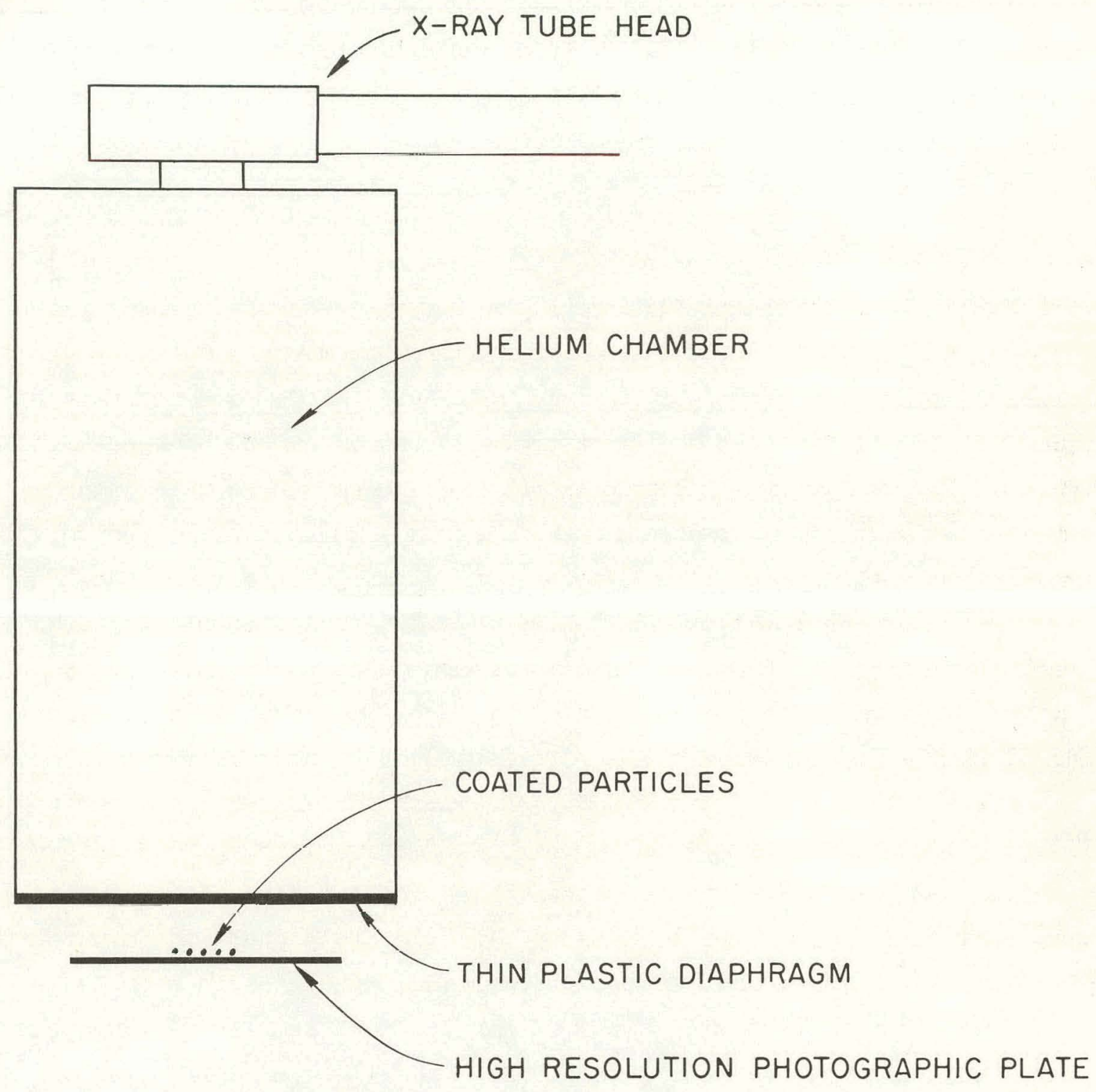

Fig. 3. Arrangement of Equipment for Coated Particle Microradiography. 
approximately $11 / 4 \mathrm{hr}$ exposure time. However, it is felt that the greater detail which resulted justified the increased time. Also, with the relatively large $x$-ray exposure field available, a number of particles from different batches could be radiographed simultaneously. To minimize the problem of geometrical unsharpness, the particles had to be in intimate contact with the emulsion. In addition, the sample had to be isolated from all external vibration that would cause movement during the exposure. A typical exposure included the following values: $10 \mathrm{kvp}, 30 \mathrm{ma}, 42-\mathrm{in}$. film-to-focus distance, and $11 / 4 \mathrm{hr}$ exposure time.

\section{Optical Microscopy}

Examination of the contact radiograph with a microscope equipped for transmitted light is the best means for observing maximum detail. Although examination can be made at 500x, a magnification of 200 diameters is usually better suited for the practical limitation of the high-resolution plates. For recording purposes, a photomicrograph can be made of a representative area of the contact radiograph. To obtain the photomicrograph, a second negative or a direct copy is made of the $1 \times$ contact radiograph with transmitted light at a magnification suitable for study, as shown in Fig. 4. For general comparisons of different batches, a magnification of 75 diameters produces a representative field; a magnification of 200 diameters, however, can be used to show more detail.

The film selected for the photomicrograph was Eastman Royal Ortho film exposed with a green (Wratten No. 54) filter, developed in DK-50 according to recommended procedures. This film satisfied the requirement that continuous tones be produced in order to capture the minute density variations of the radiographic plate. Contact prints could be made from the second negative, permitting the more fragile radiographic plate to be stored. With this technique, the light and dark areas on the final prints representing high- and low-density locations, respectively, were identical to the areas that could have been observed on the original radiograph. 


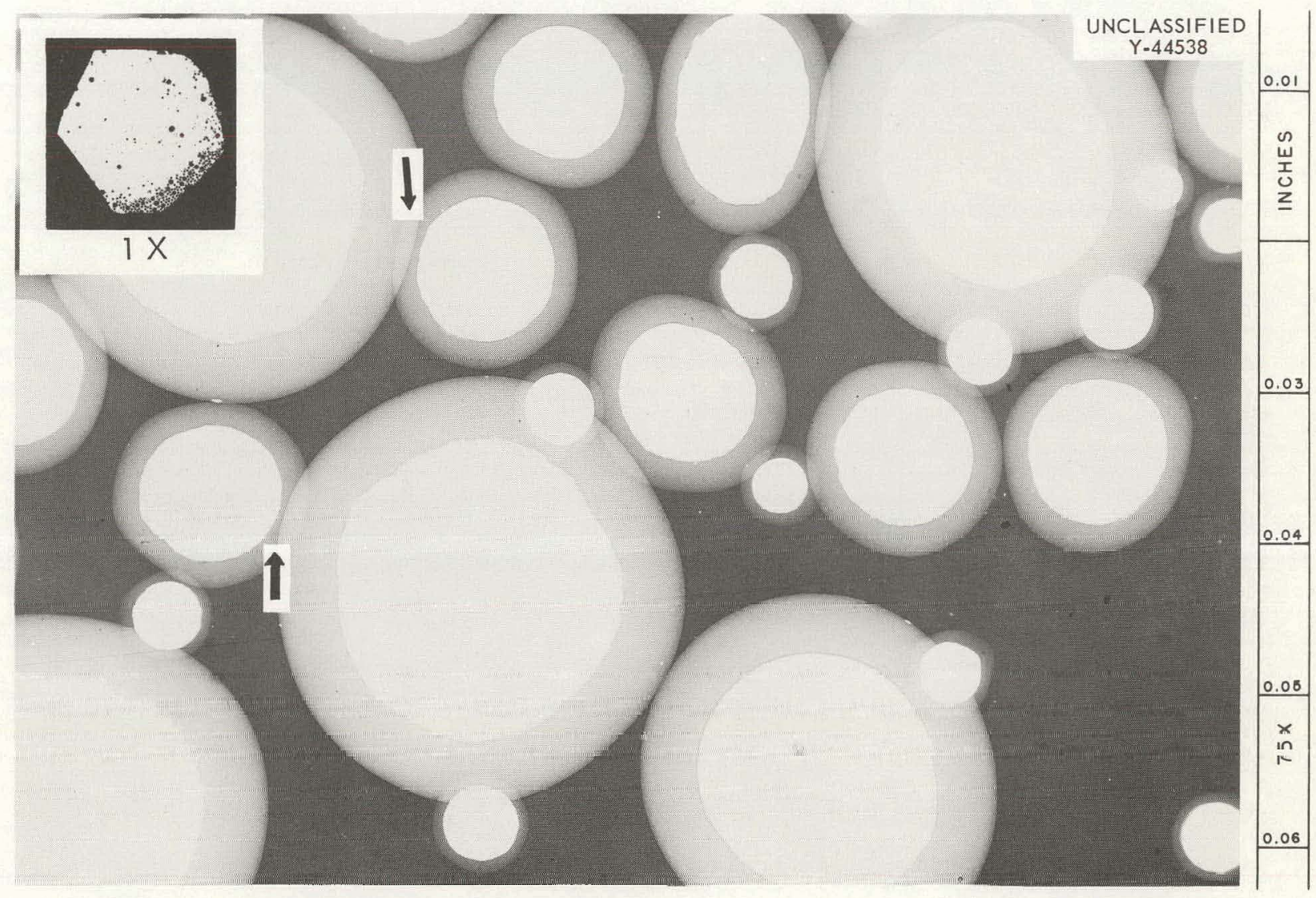

Fig. 4. Microradiographs of Intentionally Mixed Sizes of Coated Uranium Carbide Particles. Inset shows the original exposure (IX); arrows indicate overlap of a large sphere with a smaller sphere. 
Results and Conclusions

The metallographic examination of coated uranium carbide is extremely worthwhile in evaluating the composition of the fuel, the presence of impurities, and the general microstructure of the core, coating, and interface, including relatively gross microstructural diffusion which may have occurred. Some mensuration can be done; however, there is always the question of whether the examination is being made on a median plane for maximum accuracy. Conditioning the particles for metallographic examination limits their further use.

The microradiographic technique is a relatively rapid, nondestructive approach ideal for measuring core and coating thicknesses and, due to the great difference in densities of fuel and coating, enables diffusion to be detected. An additional advantage of the modified radiographic technique became apparent when, as shown in Fig. 5, particles were observed containing no core and porous (or low-density) cores, as well as the high-density (fuel) material in the coating. Since in this method the particle is looked at as a whole, information not detectable from a plane by microstructural examination becomes available; on the other hand, minute of microstructure cannot be obtained.

A primary problem in making the microstructural examination concerns detection of possible high-temperature diffusion of the fuel core into the coating. Although metallic fuel precipitates of 0.0002 in. or greater in the coating can be detected by metallography, smaller fuel precipitates in the coating blend in so well with the mottled and speckled appearance of the pyrolytic coating that they are extremely difficult to distinguish. Figure 6a shows localized particles of uranium dicarbide $\left(\mathrm{UC}_{2}\right)$ within the pyrolytic carbon and some graphite dispersed within the fuel core. A microradiograph (Fig. 6b) of similar material from the same batch shows density variations extending to the surface of the pyrolytic carbon coating; there is no evidence, however, of carbon which is located in the core matrix. Due to the large difference in densities of the uranium carbide and the pyrolytic carbon, a small amount of uranium carbide in the coating can be detected by the microradiographic technique, but small amounts of graphite in the uranium carbide cannot be detected. 


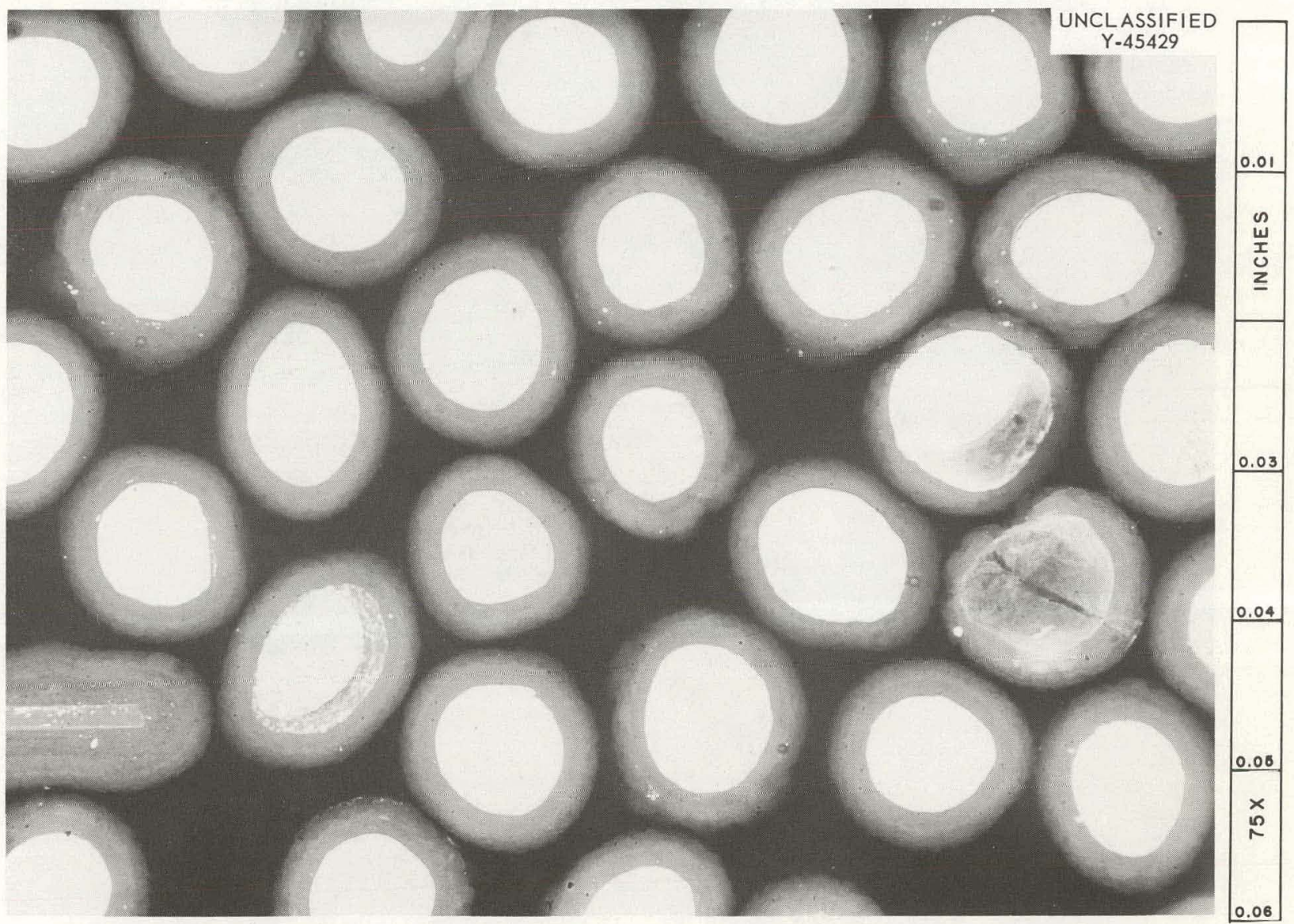

Tig. 5. Microradiograph of Coated Uranium Carbide Particles. Note the detection of cores which exhibit porosity and major fractures, the ability to show relative core/coating dimensions, and the absence of cores as well as high-density fuel cores. 

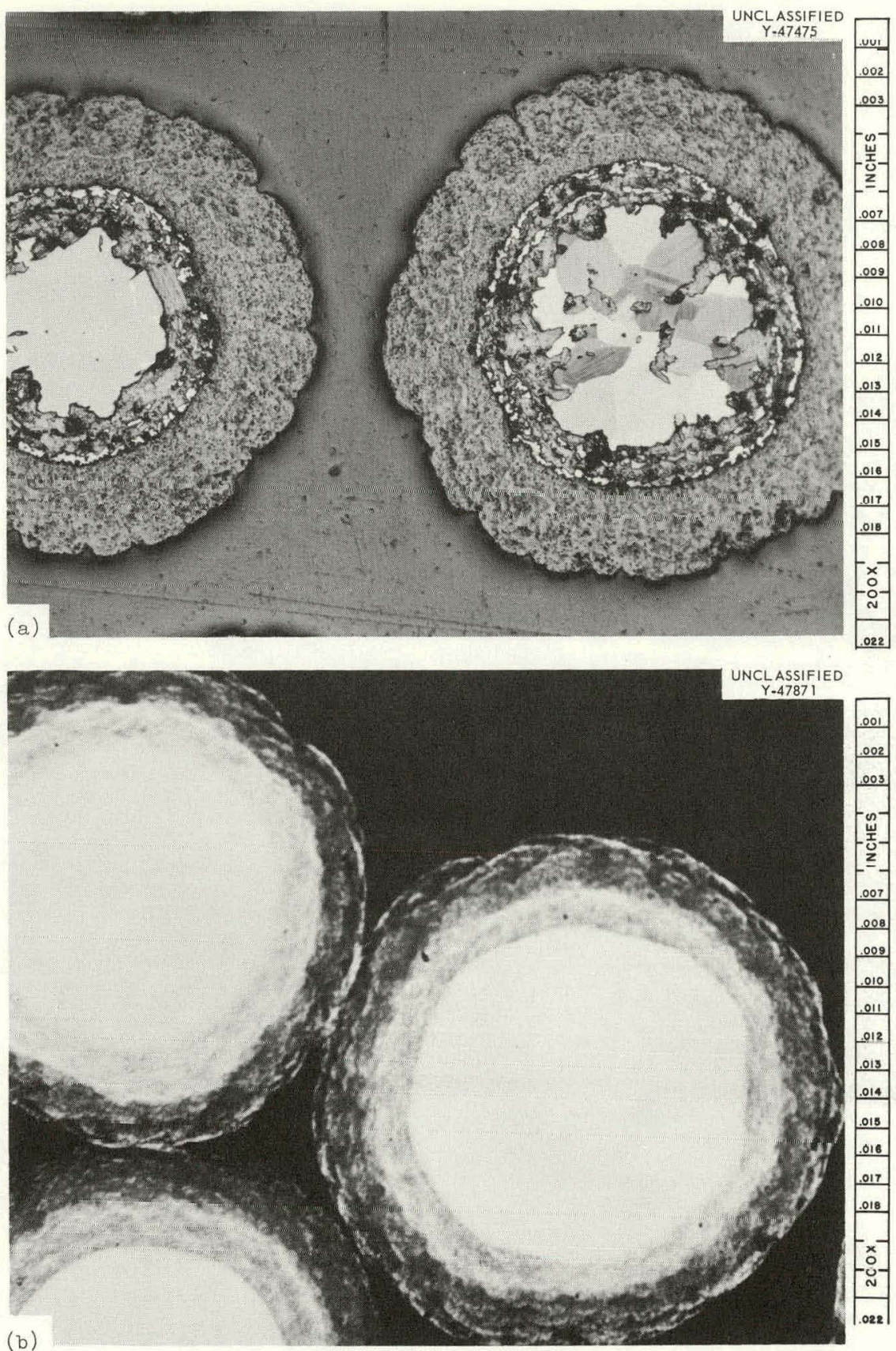

Fig. 6. Mntallographic vs Microradiographic Procedure of Similar Coated Particles. (a) Metallographic procedure. Note diffusion of pyrolytic carbon into fuel core. Some isolated fuel particles can be seen in the carbon matrix. Uranium carbide etchant: equal parts $\mathrm{HNO}_{3}$, $\mathrm{CH}_{3} \mathrm{COOH}, \mathrm{H}_{2} \mathrm{O}$. (b) Microradiographic procedure. The diffusion of fuel material into the pyrolytic carbon coating appears to be deeper in the microradiographic than is evident by the metallographic procedure. Reduced 29\%. 
Figures $7 \mathrm{a}$ and $\mathrm{b}$ are a photomicrograph and microradiograph, respectively, of particles from the same batch of coated uranium-thorium carbide. Although the overall particle size and shape are better defined in the microradiograph, grain details are evident in the photomicrograph of the core. Fractured particles, such as can be seen in Fig. 8, are more easily identified by microradiography, but, although the general character of the coating is evident, much more coating detail is available in the photomicrograph.

From the few illustrations selected to show particle defects, it is obvious that each method has distinct advantages for the evaluation of coated particles and that each has certain limitations. Since the weak points of one correspond to the strong points of the other, in combination as a complementary team they provide a more useful and complete evaluation. Appropriate use of the two techniques during developmental stages and as a quality-control tool for coated particles should do much toward the attainment of higher temperature, lower cost, nuclear reactors for power generation.

\section{Acknowledgments}

The authors wish to recognize the contributions of $\mathrm{J}$. L. Cook, C. K. H. DuBose, T. M. Kegley, B. C. Leslie, and W. J. Mason to the work reported here. They are principally responsible for converting the several ideas on ways of examining coated particles into a practical procedure. The editorial work of Virginia Hamrick and the patience of the Reports Office through the various draft stages are sincerely appreciated. 

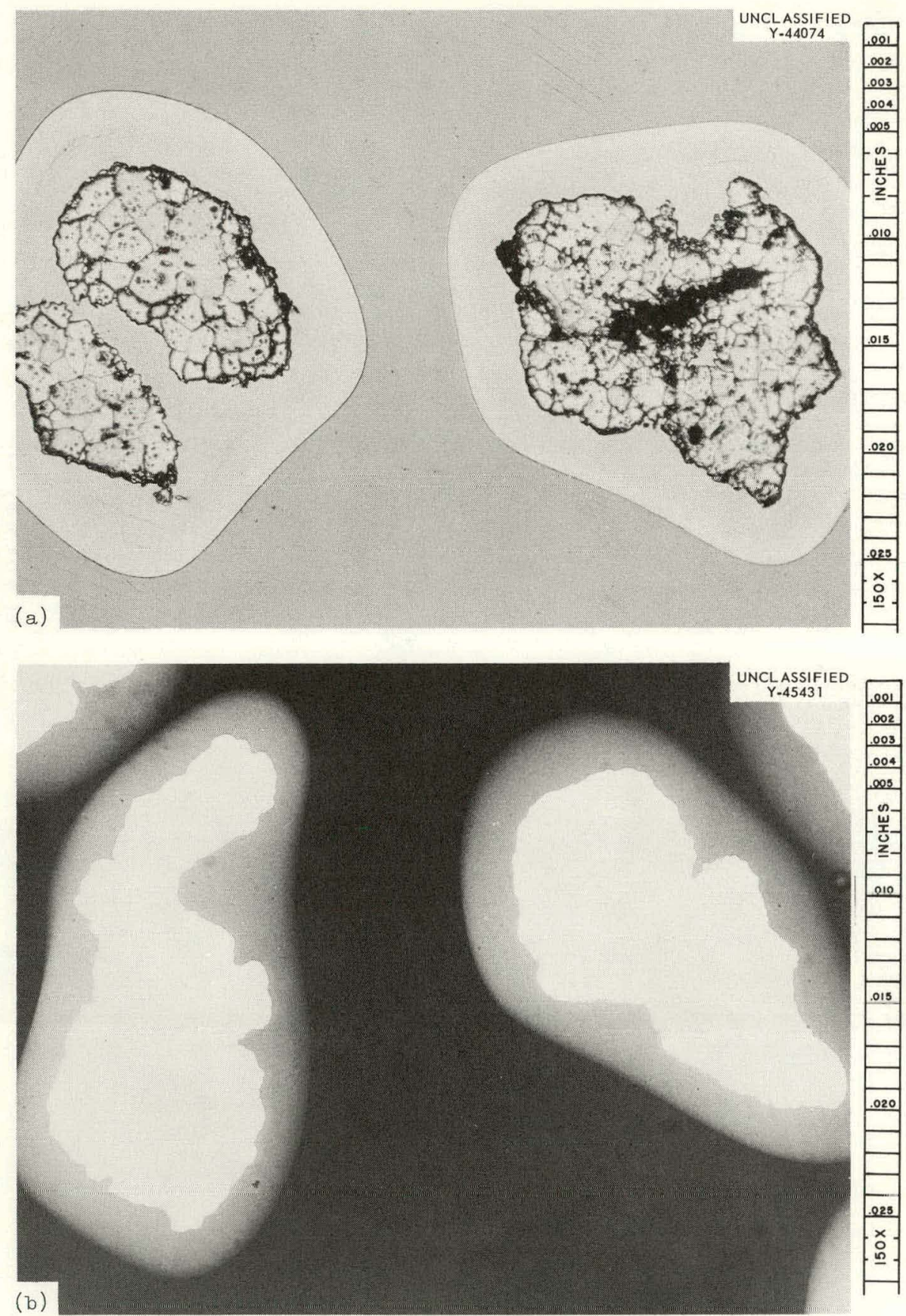

Fig. 7. Metallographic vs Microradiographic Procedure of Same Batch of Coated Uranium-Thorium Carbide. (a) Metallographic procedure. Airetched to show grain size of core. The apparent duplex core particles may be attributed to the shape and plane of examination. (b) Microradiographic procedure. A more representative presentation of the overall geometry is shown by this technique. Reduced $26 \%$. 

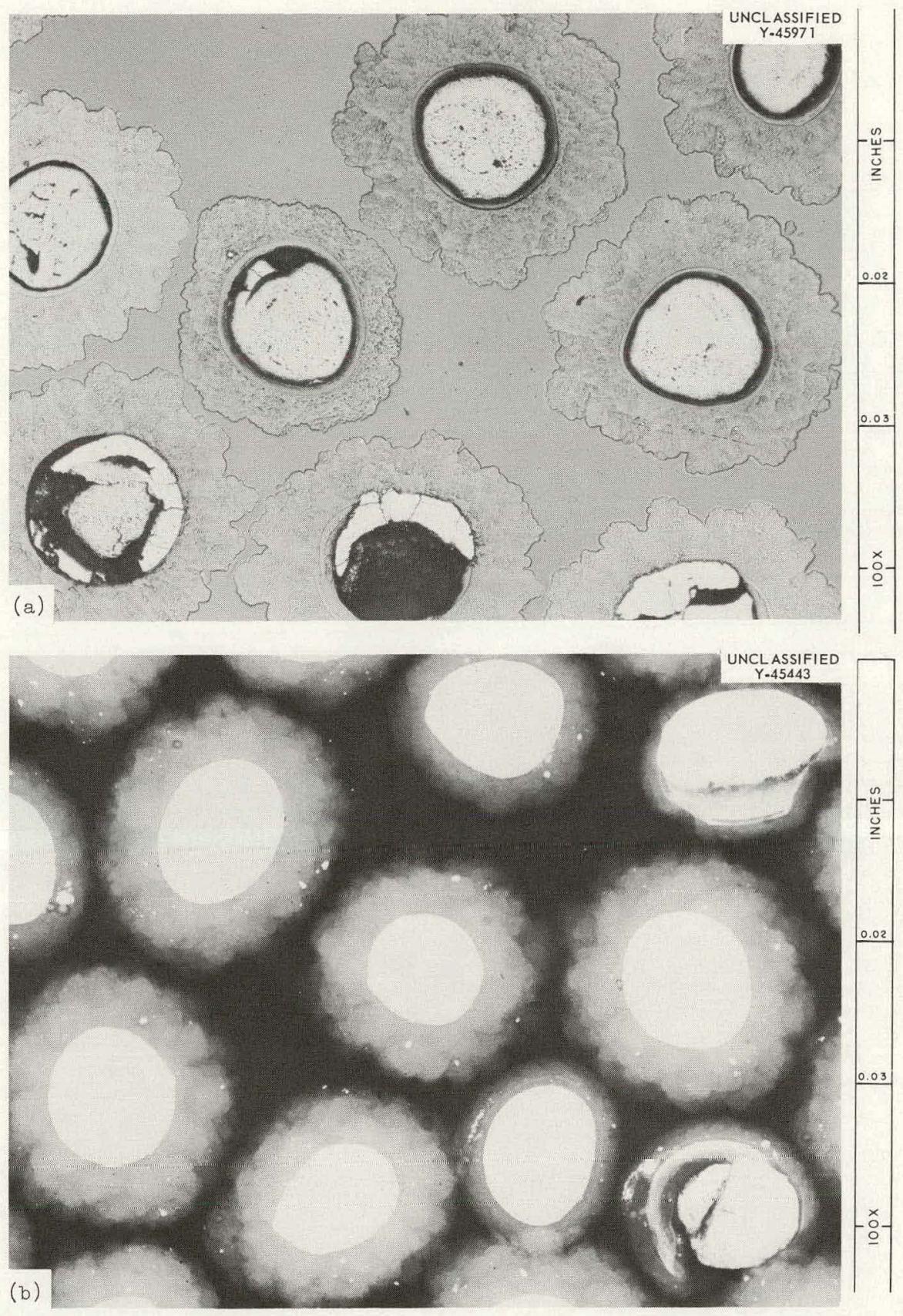

Fig. 8. Metallographic vs Microradiographic Procedure for the Same Batch of Coated Uranium Carbide. (a) Metallographic procedure. Note the fragmentation of the fuel core; some fragments undoubtedly were lost in preparation. Unetched. (b) Microradiographic procedure. Note the fragmentation of the fuel core and the ability of this technique to show the detail of the coating. Reduced $27 \%$. 
THIS PAGE

\section{WAS INTENTIONALLY \\ LEFT BLANK}




$$
\begin{gathered}
\text { ORNL-3577 } \\
\text { UC-25 - Metals, Ceramics, and Materials } \\
\text { TID-4500 (30th ed.) }
\end{gathered}
$$

\begin{tabular}{|c|c|c|c|}
\hline $1-3$. & Central Research Library & 49. & C. E. Larson \\
\hline 4. & Reactor Division Library & 50. & C. F. Leitten, Jr. \\
\hline $5-6$. & ORNL - Y-12 Technical Librar & 51. & A. L. Lotts \\
\hline & Document Reference Section & 52. & MacPherson \\
\hline $7-26$ & Laboratory Records Department & $53-97$. & W. D. Manly \\
\hline 27. & Laboratory Records, ORNL R. C. & 98. & M. M. Martin \\
\hline 28. & ORNL Patent Office & $99-103$. & R. W. McClung \\
\hline 29. & R. E. Adams & 104. & M. F. Osborne \\
\hline 30. & R. J. Beaver & 105. & M. L. Picklesimer \\
\hline 31. & E. S. Bomar & 106. & S. A. Rabin \\
\hline 32. & J. C. Bresee & 107. & R. E. Reed, Sr. \\
\hline 33. & F. L. Carlsen, Jr. & 108. & B. F. Roberts \\
\hline 34. & J. L. Cook & 109. & M. W. Rosenthal \\
\hline 35. & J. E. Cunningham & 110. & J. L. Scott \\
\hline 36. & O. C. Dean & 111. & C. M. Smith \\
\hline 37. & H. W. Dunn & 112. & G. M. Slaughter \\
\hline 38. & R. B. Fitts & 113 . & O. Sisman \\
\hline 39. & J. H Frye, Jr. & 114. & J. A. Swartout \\
\hline 40. & T. G. Godfrey & 115. & G. M. Tolson \\
\hline 41. & A. Goldman & 116. & A. M. Weinberg \\
\hline 42. & R. J. Gray & 117. & D. E. Wilson \\
\hline 43. & George Hallerman & 118. & A. A. Burr (consultant) \\
\hline 44. & W. O. Harms & 119. & J. R. Johnson (consultant) \\
\hline $5-47$ & M. R. Hill & 120. & C. S. Smith (consultant) \\
\hline 48. & T. M. Kegley, Jr. & 121. & $\begin{array}{l}\text { R. Smoluchowski } \\
\text { (eonsultant) }\end{array}$ \\
\hline
\end{tabular}

\section{INTERNAI DISTRIBUTION}

EXTERNAL DISTRIBUTION

122. C. M. Adams, Jr., Massachusetts Institute of Technology

1'3. D. F. Raker, General Electric, Hanford

124. M. N. Burkett, Carbon Products Division, Lawrenceburg, Tennessee

125-126. D. F. Cope, Oak Ridge Operations Office

127. Frsel Evans, General Electric, Hanford

128. W. V. Goeddel, General Atomics

129. J. L. Gregg, Cornell University

130. W. E. Parker, Research and Development Laboratories, Niagara Falis

331. Research and Development, Oak Ridge Operations.

132. R. Rowand, Wright-Patterson AFB

133. J. Simmons, U. S. Atomic Energy Commission, Washington, D.C.

134. Harold G. Sowman, The 3M Company, St. Paul, Minnesota

135. E. E. Stansbury, University of Tennessee, Knoxville

L36. D. K. S'tevens, U. S. Atomic Energy Commission, Washington, D.C. 137-637. Given aistribution as shown in TID-4500 (30th ed.) under Metals, Ceramics, and Materials category. 